\title{
POLA SERANGGA NEKROFAGUS PADA DEKOMPOSISI HEWAN COBA INDOORS DI KOTA MANADO
}

\author{
${ }^{1}$ Sunny Wangko \\ ${ }^{2}$ Erwin G. Kristanto \\ ${ }^{1}$ Sonny J. R. Kalangi \\ ${ }^{1}$ Bagian Anatomi-Histologi Fakultas Kedokteran \\ ${ }^{2}$ Bagian Forensik dan Medikolegal Fakultas Kedokteran \\ Universitas Sam Ratulangi Manado \\ Email: sunnywangko@yahoo.com
}

\begin{abstract}
Studies of insect succession in indoor carcasses are still very rare reported. This study aimed to obtain the succession pattern of necrophagus insects in indoor carcass in Manado. One domestic pig was used as model, and killed with a cardiac puncture. The results showed that the duration of decomposition took 16 days to reach skeletonization. There were 3 orders found, as follows: Diptera, Coleoptera, and Hymenoptera, consisting of 8 families and 12 species. Albeit, insects that colonized in the carcasses were Chrysomya rufifacies, Chrysomya megacephala, Sarcophaga harpax, Hermetia illucens, Dermestes maculatus, and several species of Muscidae. Both species of Chrysomya and Sarcophaga harpax can be applied in PMI estimation at early stage of decomposition meanwhile Hermetia illucens and Dermestes maculatus at late stage of decompostion. To our knowledge, this is the first study of decomposition and insect succession indoors in a coastal area in Indonesia. Moreover, this is the first report of Sarcophaga harpax which is biomolecularly identified with mtDNA in Indonesia. Further studies are needed to support the database of forensic insects in Indonesia, especially in Manado.
\end{abstract}

Keywords: decomposition, indoors, necrophagus insects, colonization

\begin{abstract}
Abstrak: Studi mengenai suksesi serangga indoors masih sangat jarang dilaporkan. Penelitian ini bertujuan untuk mendapatkan pola serangga nekrofagus pada bangkai hewan coba indoors di Manado. Sebagai hewan coba digunakan satu ekor babi domestik yang dimatikan dengan tusukan pada jantung. Hasil penelitian memperlihatkan dekomposisi hewan coba indoors di kota Manado memerlukan 16 hari untuk mencapai skeletonization. Serangga yang berkunjung ke hewan coba tergolong dalam 3 ordo, yaitu: Diptera, Coleoptera, dan Hymenoptera, yang terdiri atas 8 famili dan 12 spesies. Serangga yang ditemukan berkolonisasi pada bangkai hewan coba ialah Chrysomya rufifacies, Chrysomya megacephala, Sarcophaga harpax, Hermetia illucens, Dermestes maculatus, dan beberapa spesies Muscidae. Kedua spesies Chrysomya dan Sarcophaga harpax dapat dimanfaatkan dalam perkiraan PMI pada dekomposisi awal, sedangkan Hermetia illucens dan Dermestes maculatus dapat dimanfaatkan pada dekomposisi lanjut. Penelitian mengenai dekomposisi dan suksesi serangga indoors ini merupakan yang pertama di daerah pesisir di Indonesia. Terdapatnya Sarcophaga harpax yang diidentifikasi secara biomolekular dengan mtDNA juga merupakan yang pertama kali dilaporkan di Indonesia. Studi lanjut dibutuhkan untuk menyokong database serangga forensik di Indonesia, khususnya Manado.
\end{abstract}

Kata kunci: dekomposisi, indoors, serangga nekrofagus, kolonisasi 